\title{
Effect of Volcanic Pumice on the Corrosion Resistance and Chloride Diffusivity of Blended Cement Mortars
}

\author{
Khandaker M. Anwar Hossain
}

Received 4 October 2002, accepted 26 February 2003

\begin{abstract}
This paper reports the results of investigation on the chloride diffusivity and corrosion resistance of volcanic pumice (VP) blended cement mortars with varying curing age of up to one year. The mortars had $0,15 \%$ and $30 \%$ VP as cement replacement and water/binder ratio of 0.55 . Tests were conducted to determine the chloride ion migration coefficient $\left(\mathrm{D}_{\mathrm{i}}\right)$ of the mortars. In addition, electrical resistivity, mercury intrusion porosimetry, and differential scanning calorimetry (DSC) tests were conducted. Electrochemical measurement was used to monitor the corrosive behaviour of the embedded steel bars. It was found that blending cement with VP significantly reduced the long-term Di and hence increased the long-term corrosion resistance of mortars. This fact was also supported by the presence of lower quantity of $\mathrm{Ca}(\mathrm{OH})_{2}$ and higher quantity of Friedel's salt in the VP blended mortars as observed from the DSC tests. Mortars with $30 \%$ VP showed better performance in terms of chloride ion diffusivity, chloride ingress and passivation period of embedded steel compared to control mortar with $0 \%$ VP.
\end{abstract}

\section{Introduction}

The search for alternative binders or cement replacement materials has been continued for the last decades. Research has been carried out on the use of volcanic ash (VA), volcanic pumice (VP), fly ash (FA), pulverizedfuel ash (PFA), blast furnace slag, rice husk ash, silica fume etc. as cement replacement material (Hossain 1998a, 1998b; Al-Ani et al. 1989; Mehta 1979; Swamy 1983, 1986; Berry et al. 1980; Bilodeau et al. 1998). The VA, VP, PFA and FA are pozzolanic materials, because of their reaction with lime (Calcium hydroxide) liberated during the hydration of cement. Amorphous silica present in the pozzolanic materials combines with lime and forms cementitious materials. These materials can also improve the durability of concrete and the rate of gain in strength and can also reduce the rate of liberation of heat, which is beneficial for mass concrete. The reactivity of fly ash has been found to depend on the mineral substitution in the glassy silica structure. Fly ashes containing high amounts of calcium oxide have both cementing and pozzolanic activity while those containing mainly aluminium oxide and iron oxide as the major mineral substitution in the structure of the silica glass only has pozzolanic activity. Studies have been published concerning the effect of fly ash on concrete porosity and resistivity, pore solution chemistry, oxygen and chloride ion diffusivity (Thomas et al. 1996; Mangat et al. 1987), carbonation rates (Montemor et al. 1993), passivation (Montemor et al. 1998) and corrosion resistance (Montemor et al. 2000) especially chlorideinduced corrosion.

Comprehensive research had been conducted over the

Department of Civil Engineering, Ryerson University, Canada.E-mail: dr_k_m_hossain@hotmail.com last few years on the use of VA and VP in cement and concrete production (Hossain 1998a, 1999a, 1999b; Hossain et al. 1999). The meaningful use of such volcanic debris can transform them into natural resources and can not only provide low cost cement and concrete but can also help to decrease environmental hazard in volcanic areas of the world. Research suggests that the manufacture of blended PVAC (Portland volcanic ash cement) and PVPC (Portland volcanic pumice cement) similar to PFAC (Portland fly ash cement) is possible with maximum replacement of up to $15 \%$ (Hossain 1998a).

Durability of concrete is one of its most important properties and it is essential that the concrete made with VA and VP blended cement should be capable of preserving its durability throughout the life of structures. Until recently (Hossain 1999c) little research has been conducted on the degradation of VP blended concrete subjected to aggressive environment. The problem of corrosion of steel in concrete is very important. The diffusion of chloride ions through concrete is a major cause of corrosion of reinforcing bars in offshore structures as well as highway bridges in cold countries where deicing salts $\left(\mathrm{NaCl}\right.$ and $\left.\mathrm{CaCl}_{2}\right)$ are used during the winter.

The diffusivity of chloride through concrete depends on the microstructure of the concrete and mortar. Blending cement with cementitious materials like fly ash is known to produce concrete and mortar with a dense microstructure (Kawamura et al. 1989) and hence an improvement in the physical protection of any embedded bars. In addition to this, if there were the chloride binding by the aluminate phase to form Friedel's salt, then the concentration of the free chloride ions in the pore water of concrete/mortar would be expected to decrease. Currently informations are not available on the chloride binding or corrosion inhibition characteristics in VP blended cement mortar/concrete. Quantitative 
Table 2 Mortar mix proportions and fresh density.

\begin{tabular}{|l|c|c|c|c|c|c|}
\hline Specimen & $\mathrm{W} /(\mathrm{C}+\mathrm{VP})$ & $\begin{array}{c}\text { Water }(\mathrm{W}) \\
{[\mathrm{kg}]}\end{array}$ & $\begin{array}{c}\text { Cement }(\mathrm{C}) \\
{[\mathrm{kg}]}\end{array}$ & $\begin{array}{c}\mathrm{VP} \\
{[\mathrm{kg}]}\end{array}$ & $\begin{array}{c}\text { Sand } \\
{[\mathrm{kg}]}\end{array}$ & $\begin{array}{c}\text { Fresh mortar } \\
\text { density }\left[\mathrm{kg} / \mathrm{m}^{3}\right]\end{array}$ \\
\hline $0 \% \mathrm{VP}$ (control) & 0.55 & 0.55 & 1 & 0 & 3 & 2180 \\
\hline $15 \% \mathrm{VP}$ & 0.55 & 0.55 & 0.85 & 0.15 & 3 & 2140 \\
\hline $30 \% \mathrm{VP}$ & 0.55 & 0.55 & 0.70 & 0.30 & 3 & 2110 \\
\hline
\end{tabular}

Mortar mix proportions are based on $1 \mathrm{~kg}$ of $\mathrm{C}+\mathrm{VP}$

representation for the chloride binding ability of VP is necessary.

This paper describes the chloride ion diffusivity of VP blended Portland cement mortars. It also presents the chloride binding ability of VP to form Friedel's salt. The beneficial effect of VP on the chloride ion diffusivity and corrosion inhibition is vital for the use of VP blended cement in concrete construction subjected to marine environment or deicer salt.

\section{Experimental procedure}

\subsection{Materials and mix proportions}

The volcanic pumice (VP) used in this investigation was collected from the Rabaul area of the East New Britain province of Papua New Guinea and the source was a volcano called Mount Tavurvur. The Rabaul area is situated in the worldwide earthquake and volcanic zone known as the 'Belt of fire'. The cement used was locally manufactured normal Portland cement (NPC) conforming to ASTM Type I.

Chemical and physical characters of VP and NPC are presented in Table 1. VP is principally composed of sili-

Table 1 Chemical and physical characters.

\begin{tabular}{|c|c|c|}
\hline Chemical characters & VP & $\begin{array}{c}\text { NPC } \\
\text { (ASTM Type I) }\end{array}$ \\
\hline \multicolumn{3}{|l|}{ Chemical compounds [mass \%] } \\
\hline Calcium oxide $(\mathrm{CaO})$ & 4.44 & 64.1 \\
\hline Silica $\left(\mathrm{SiO}_{2}\right)$ & 60.82 & 21.4 \\
\hline Alumina $\left(\mathrm{Al}_{2} \mathrm{O}_{3}\right)$ & 16.71 & 5.7 \\
\hline Iron oxide $\left(\mathrm{Fe}_{2} \mathrm{O}_{3}\right)$ & 7.04 & 3.5 \\
\hline Sulphur trioxide $\left(\mathrm{SO}_{3}\right)$ & 0.14 & 2.1 \\
\hline Magnesia $(\mathrm{MgO})$ & 1.94 & 2.1 \\
\hline Sodium oxide $\left(\mathrm{Na}_{2} \mathrm{O}\right)$ & 5.42 & 0.5 \\
\hline Loss on ignition & 1.52 & 1.1 \\
\hline \multicolumn{3}{|l|}{ Physical and strength characters } \\
\hline Fineness $\left[\mathrm{m}^{2} / \mathrm{kg}\right]$ & 290 & 320 \\
\hline Passing $45 \mu \mathrm{m}$ sieve [\%] & 88 & 94 \\
\hline Residue on $75 \mu \mathrm{m}$ sieve [\%] & 2.5 & $0.1-1.5$ \\
\hline Density $\left[\mathrm{kg} / \mathrm{m}^{3}\right]$ & 1960 & 3150 \\
\hline Compressive strength of & & \\
\hline $50 \mathrm{~mm}$ cubes $[\mathrm{MPa}]$ 7-day & - & 26 \\
\hline 28-day & - & 32 \\
\hline
\end{tabular}

ca (about $60 \%$ ) while the main component of cement is calcium oxide (maximum $70 \%$ ). VP also has compounds like calcium oxide, alumina and iron oxide (total about 31\%). The Blaine fineness and density of finely grounded VP are $290 \mathrm{~m}^{2} / \mathrm{kg}$ and $1960 \mathrm{~kg} / \mathrm{m}^{3}$. VP satisfies the requirement of Class $\mathrm{F}$ fly ash as per ASTM C618 (1991). The NPC has a density of $3150 \mathrm{~kg} / \mathrm{m}^{3}$ and Blaine fineness of $320 \mathrm{~m}^{2} / \mathrm{kg}$.

River sand of fineness modulus 2.40 having a density of $2650 \mathrm{~kg} / \mathrm{m}^{3}$ and water absorption of 0.6 percent was used. Ordinary drinking water was used in the mortar mixes. These materials were used to prepare the mortar mixes with $\mathrm{W} /(\mathrm{C}+\mathrm{VP})$ ratio of 0.55 . VP replacement percentages of $15 \%$ and $30 \%$ by mass were used in the mortar mixes. In addition control specimens were prepared without VP $(0 \%)$. The ratio of cementing materials (Cement + VP) to sand was 1:3 by mass. Table 2 shows the mixture proportions of the mortars.

Cylindrical specimens having $100 \mathrm{~mm}$ in diameter and $200 \mathrm{~mm}$ in height, $50 \mathrm{~mm}$ diameter and $100 \mathrm{~mm}$ in height, $70 \mathrm{~mm}$ cubes and mortar blocks with steel bars (Fig. 1) were cast to carry out the tests.

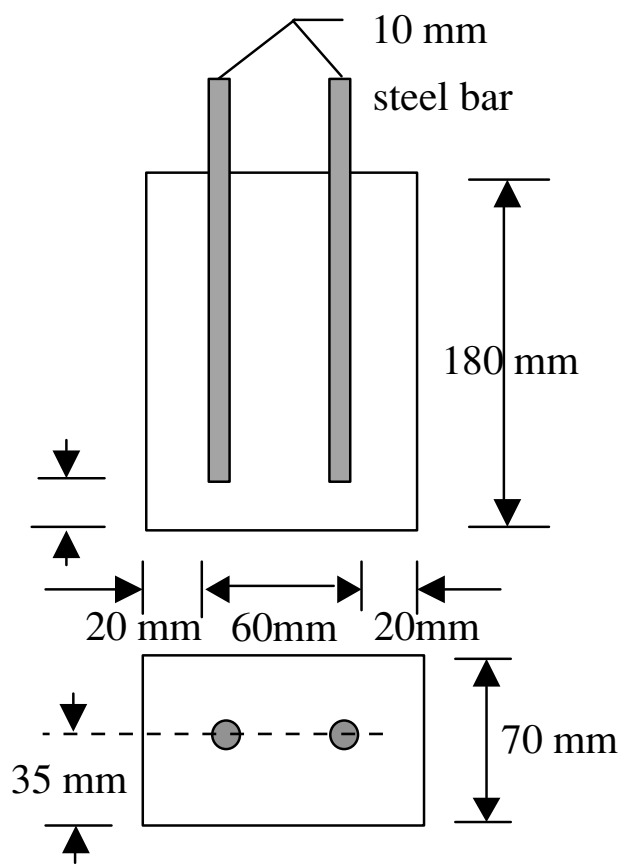

Fig. 1 Schematic of the mortar blocks with embedded steel bars. 


\subsection{Evaluating methods}

\section{(1) ACID test on mortar}

The accelerated chloride ion diffusion (ACID) test (Gjorv 1994; Tang et al. 1992; Zhang et al. 1994), an improvement over the rapid chloride permeability test (AASHTO T277 1983), was used to determine the chloride ion diffusion coefficient of mortars. In this test, a diffusion cell (volume: $785 \mathrm{ml}$ ) using 3 mass \% $\mathrm{NaCl}$ and $0.3 \mathrm{~N} \mathrm{NaOH}$ as cathode and anode solutions respectively was used. The tests were conducted at 7, 28, 91 and 180 days of moist curing of the specimens. Mortar specimen (100 mm diameter x $20 \mathrm{~mm}$ thick) was placed between the electrodes and an electric field of $3 \mathrm{~V} / \mathrm{cm}$ was applied to the electrodes. The amount of chloride ions $\left(\mathrm{Cl}^{-}\right)$that migrated from the cathode through the mortar specimen to the anode of the cell was determined by measuring the concentration of the chloride ions in the anode solution periodically. The amount of $\mathrm{Cl}^{-}$vs. the number of days graph could be approximated as a straight line (Fig. 2) and the slope of this straight line, is termed as chloride ion flux $\left(\mathrm{f}_{\mathrm{i}}\right) . \mathrm{f}_{\mathrm{i}}$ was used in the Nernst-Plank's equation (Eq.1) to calculate the migration coefficient $\left(D_{\mathrm{i}}\right)$ (Gjorv 1994; Tang et al. 1992):

$$
D_{i}=\frac{R \cdot T \cdot f_{i}}{I_{c} \cdot F \cdot C_{i} \delta V}
$$

where $D_{\mathrm{i}}=$ migration coefficient in $\mathrm{cm}^{2} / \mathrm{s}, R=$ universal gas constant $=8.314 \mathrm{~J} / \mathrm{K} \cdot \mathrm{mol}, T=$ temperature in Kelvin, $I_{\mathrm{c}}=$ ionic charge of chloride ion, $F=$ Faraday constant $=9.65 \times 10^{4} \mathrm{C} / \mathrm{mol}, C_{i}=$ chloride ion concentration in the anode chamber of the diffusion cell and $\delta V=$ electric field in $\mathrm{V} / \mathrm{cm}$.

It should be noted that the basis of the determination of $\mathrm{Cl}^{-}$migration coefficient out of migration tests is a constant flux of $\mathrm{Cl}^{-}$from the cathode chamber through the sample into the anode chamber. Such a constant flux of chloride ions really does not exist, as there are two mechanisms of influence: (a) chloride binding/debinding in cement and (b) the changes of $\mathrm{OH}^{-}$concentration in the

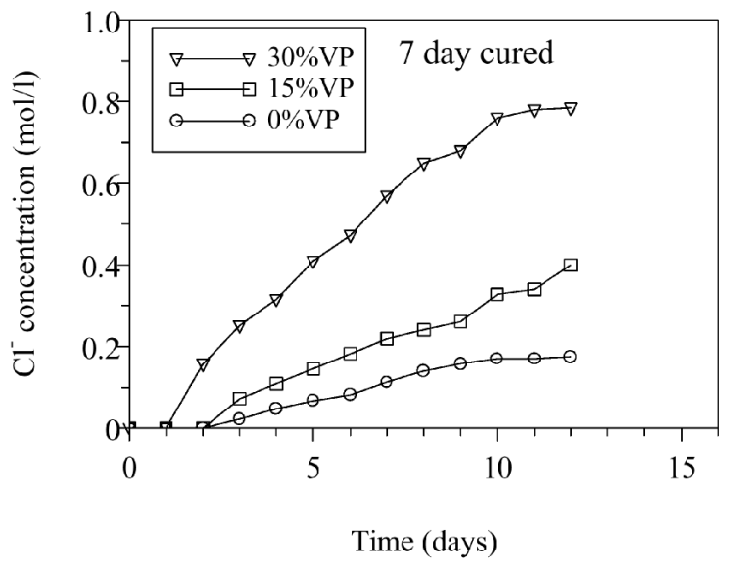

Fig. 2 Typical variation of $\mathrm{Cl}^{-}$concentration in the anode chamber with time. electrode chambers due to the reactions at the electrodes. The electrochemical reaction that occurs at the electrodes results in a marked increase in the $\mathrm{OH}^{-}$concentration of the pore solution in the zone of the sample close to the cathode, whereas a steep decrease is observed in the zone of the sample facing the anode (Tritthart 1999). This phenomenon influences the chloride transference number and the used ACID test method does not necessarily lead to the same migration coefficients as natural diffusion tests.

\section{(2) Electrical resistivity of mortar}

The electrical resistivity was measured with an Inductance-Capacitance-Resistance/ Impedance (LCR) meter (Model: Instek LCR-817) by applying a $10 \mathrm{mV} \mathrm{AC}$ at 1 $\mathrm{kHz}$ across saturated specimens having wet surface condition (50 mm diameter x $50 \mathrm{~mm}$ thick) using copper plate electrodes. The instrument gave a digital display of the value of the electrical resistance/impedance. The value of the resistance measured was then used to calculate the electrical resistivity taking into account of the mortar thickness across which measurements were made. The tests were conducted at 7, 28, 91 and 180 days of moist curing of the mortar specimens.

\section{(3) Total pore volume (TPV) of mortar}

The mercury intrusion porosimetry was used to measure the total pore volume of the cement and cement-VP mortars. The tests were conducted at 7, 28, 91 and 180 days of moist curing of the mortar specimens. After the required period of curing, mortar samples of up to $5 \mathrm{~g}$ mass were taken from the middle central region of each of the $70 \mathrm{~mm}$ cube and dried in a sealed cabinet at 400C under silica gel. When samples reached a constant mass (normally within 48 hours), they were stored in an airtight container. The samples were then broken further and subsequently used (1-2 g mass) for mercury intrusion porosimetry testing.

Two Fisons (Italy) instruments were used for mercury intrusion porosimetry, the Macropore Unit 120 and the Porosimeter 2000WS. The macropore unit was used to fill the dilatometer containing the sample with mercury under vacuum at $100 \mathrm{KPa}$. It also allowed the macropore measurements to be performed by releasing the vacuum pressure slowly and noting the intruded volume at each pressure increment. The macropore measurements were completed when the pressure reaches atmospheric pressure. The porosimeter $2000 \mathrm{WS}$ was used to perform the high pressure measurements and had a capacity of $200 \mathrm{MPa}$. It was able to measure pores with radii down to $0.004 \mu \mathrm{m}$. The Washburn equation (Washburn 1921) was used to calculate the pore radii.

The contact angle between the mercury and the pore wall of the mortar was taken as $140^{\circ}$. The total pore volume (TPV) was then expressed as the intruded mercury volume per unit mass of sample $\left(\mathrm{cm}^{3} / \mathrm{g}\right)$.

\section{(4) Compressive strength of mortar}

The tests were conducted at 7, 28, 91 and 180 days of 
moist curing of the $70 \mathrm{~mm}$ mortar cubes.

\section{(5) Chloride concentration profiling}

Cylindrical mortar specimens of $50 \mathrm{~mm}$ in diameter and $100 \mathrm{~mm}$ high were used. After demoulding, the mortar specimens were moist-cured for 7 and 28 days. After curing period, the sides and top surface of the specimens, were coated with the epoxy resin leaving the bottom surface uncoated in order to simulate a onedimensional diffusion. The specimens were then kept in an environmental chamber. While in the chamber, the specimens were sprayed with a $5 \% \mathrm{NaCl}$ solution every three days. A temperature and relative humidity of 20$25^{\circ} \mathrm{C}$ and $70-80 \%$ respectively, were maintained during exposure. After an exposure period of 365 days, the specimens were removed from the chamber. For each specimen, five discs of thickness $10 \mathrm{~mm}$ each were sliced, starting from the top surface. These were then ground into fine powder passing the $150 \mu \mathrm{m}$ sieve size. The total chloride contents were then measured (JCI-SC 5). A 2-M $\mathrm{HNO}_{3}$ solution was added to the powder, and the mixture was titrated with $0.005 \mathrm{M} \mathrm{AgNO}_{3}$ solution to determine the total chloride content of the mortar powder. The results were then used to plot graphs of the chloride content versus depth measured from the surface of the specimen.

\section{(6) Corrosion monitoring}

Mortar blocks having dimensions of $180 \times 100 \times 70 \mathrm{~mm}$ were used. Two commercial mild steel bars with $10 \mathrm{~mm}$ diameter, polished with emery paper, were embedded in each block, with a cover thickness of $20 \mathrm{~mm}$ (Fig. 1). External stainless steel plugs were connected to one end of the steel bars to serve as contact points for electrical connection. The blocks were moist cured for during 28 days. After the curing, the specimens were placed in the environmental chamber described before under same temperature and humidity conditions. While in the environmental chamber, the specimens were sprayed with a $5 \% \mathrm{NaCl}$ solution every three days.

The corrosion process of steel in concrete can be followed using several electrochemical techniques. Monitoring of open circuit potential (OCP) is the most typical procedure to the routine inspection of reinforced concrete structures (Broomfield et al. 1990). Its use and interpretation are described in the ASTM Standard Test Method for Half-Cell Potential of Reinforcing Steel in Concrete (ASTM C 876 1991). The OCP of each steel bar in this study was monitored up to an age of 180days using a high impedance voltmeter and noting the potentials against a saturated calomel electrode (SCE). ASTM standard specifies three regions of half-cell potentials to identify the initiation of corrosion of reinforcing steel based on copper sulphate electrode (CSE). Half-cell potentials more positive than $-270 \mathrm{mV} \mathrm{CSE}$ represent a passive state of corrosion while potentials more negative than $-270 \mathrm{mV}$ CSE represent an active state of corrosion (ASTM C 876 1991). ASTM C 876 (1991) standard criterion of $-350 \mathrm{mV}$ CSE representing an active state of corrosion corresponds to $-270 \mathrm{mV} \mathrm{SCE}$ of saturated calomel electrode (SCE) used in this study. The half-cell potential data collected using this technique gave a qualitative indication of the corrosion of reinforcing bars.

At the end of corrosion-monitoring test, the mortar specimens were split open, and the steel bars were carefully removed from the embedded mortars. Their corroded areas were measured. The rust on the steel bars was then removed by immersion in $10 \%$ di-ammonium hydrogen citrate solution at a temperature of $50^{\circ} \mathrm{C}$ for $24 \mathrm{~h}$. After removal, they were cleaned to remove all rust and weighed to determine their weight loss resulting from the corrosion.

\section{(7) DSC}

The differential scanning calorimetry (DSC) test was performed on the samples taken from around the steel bar to determine the quantity of Friedel's salt formed due to chloride binding and also the quantity of $\mathrm{Ca}(\mathrm{OH})_{2}$ formed in the mortars. The samples used weighted around $60 \mathrm{mg}$. The samples were heated at a constant heating rate of $10^{\circ} \mathrm{C}$ per minute to 1100 $1200^{\circ} \mathrm{C}$, in a dynamic helium atmosphere. The DSC data analysis gave graphs of heat flow between the sample and reference crucibles vs. temperature. DSC thermograms show peaks due to endothermic (heat absorbing) and exothermic (heat releasing) reactions. The $\mathrm{Ca}(\mathrm{OH})_{2}$ and Friedel's salt contents are equivalent to the area (enthalpy) under the respective endothermic peaks. The size of the area under the curve is related to the quantity of the material in the sample.

\section{Test results}

\subsection{Chloride ion migration coefficients (Di)}

Figure 2 shows the typical variation of $\mathrm{Cl}^{-}$concentration in the anode chamber with time during ACID test for 7 day cured mortar specimens with different $\%$ of VP. The $\mathrm{Cl}^{-}$flux $\left(\mathrm{f}_{\mathrm{i}}\right)$ increases with the increase of $\%$ of VP in the mortar. The $\mathrm{Cl}^{-}$flux $\left(\mathrm{f}_{\mathrm{i}}\right)$ values derived from such relationships and the number of days for $\mathrm{Cl}^{-}$to migrate from cathode to anode chamber for all the mortars are presented in Table 3.

Figure 3 shows the variation of logarithm of $D_{i}$ with curing age and with different $\%$ of VP. The $D_{i}$ decreases with the increase of curing age. The $\mathrm{D}_{\mathrm{i}}$ of cement-VP mortars decreases at a faster rate than that of $0 \% \mathrm{VP}$ with curing age. This is attributed to the beneficial effect of VP on the long-term chloride diffusivity of VP blended cement mortars. The long-term beneficial effect on chloride diffusivity is found to be better in $30 \% \mathrm{VP}$ mortar than 15\%-VP mortar.

\subsection{Electrical resistivity}

Figure 4 shows the variation of electrical resistivity with curing age and \% of VP. It can be seen that the electrical resistivity of the cement-VP mortars increases rapidly with curing time. $30 \%$ VP mortars have shown 
Table $3 \mathrm{Cl}^{-}$flux $\left(\mathrm{f}_{\mathrm{i}}\right)$ and $\mathrm{Cl}^{-}$migration time.

\begin{tabular}{|c|c|c|c|c|c|c|}
\hline \multirow{2}{*}{$\begin{array}{c}\text { Curing } \\
\text { Age (day) }\end{array}$} & \multicolumn{3}{|c|}{$\mathrm{Cl}^{-}$flux, fi (mol///day) } & \multicolumn{3}{c|}{ No. of days for $\mathrm{Cl}^{-}$migration* } \\
\cline { 2 - 7 } & $0 \% \mathrm{VP}$ & $15 \% \mathrm{VP}$ & $30 \% \mathrm{VP}$ & 0\%VP & $15 \% \mathrm{VP}$ & 30VP \\
\hline 7 & 0.0225 & 0.0364 & 0.0787 & 2 & 2 & 1 \\
28 & 0.0191 & 0.0260 & 0.0340 & 4 & 5 & 3 \\
91 & 0.0062 & 0.0125 & 0.0114 & 5 & 9 & 8 \\
180 & 0.0057 & 0.0045 & 0.0026 & 5 & 12 & 13 \\
\hline
\end{tabular}

* migration from cathode to anode chamber

substantially higher resistivity than $15 \%$ VP-mortars. On the other hand, the resistivity of the $0 \%$ cement mortar does not increase with age especially in the longterm and remains lower than the VP-mortars. Electrical current through hydrating cement mortar is electrolytic, that is, mainly due to the flow of ions through the pore spaces. Hence the electrical resistivity is an indirect measurement of porosity and diffusivity (Ping et al. 1995). In reinforced concrete structures at the onset of corrosion of the bars, the corrosion current and hence the rate of corrosion is influenced by the electrical resistivity of the concrete. The high electrical resistivity of VP blended cement mortars would enhance the overall resistivity of VP blended concrete and hence a lower rate of bar corrosion after the breakdown of passivity.

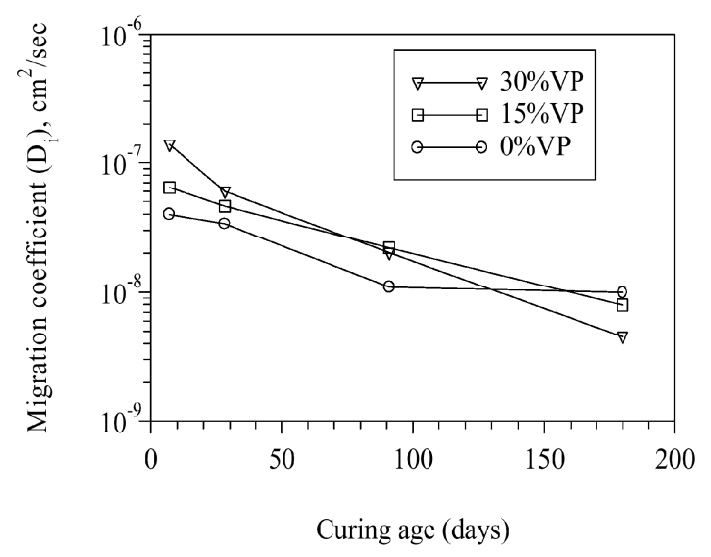

Fig. 3 Variation of $D_{i}$ with curing age and $\%$ of VP.

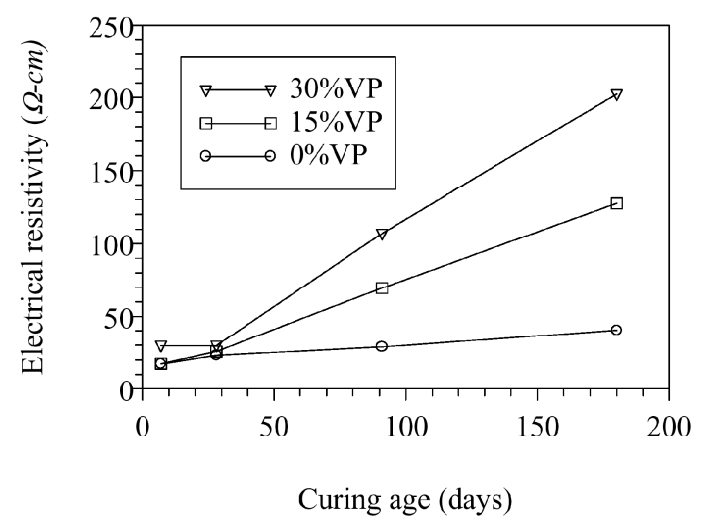

Fig. 4 Variation of electrical resistivity with curing age and $\%$ of VP.

\subsection{Total pore volume (TPV)}

The total pore volume (TPV) decreased with the increase of curing age (Fig. 5). The increase of VP content increased TPV. Mortar specimens with 30\% VP showed higher TPV than the specimens with $0 \%$ and $15 \% \mathrm{VP}$.

The effect of VP on the pore size distribution within the TPV, for pore sizes less than 20nm (micropores) and pore sizes greater than $20 \mathrm{~nm}$ (macropores) at different curing ages is presented in Fig. 6. Figure 6 plotted the percentage of TPV less than or greater than $20 \mathrm{~nm}$ against the curing age. It is noted that increasing levels of replacement of cement with VP (up to $30 \%$ ) produce a refinement of pore structure of the mortar.

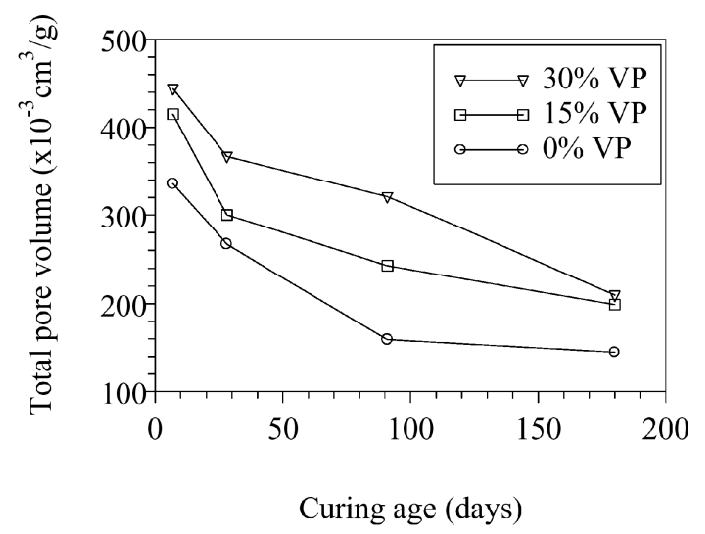

Fig. 5 Total pore volume as a function of curing age and VP content.

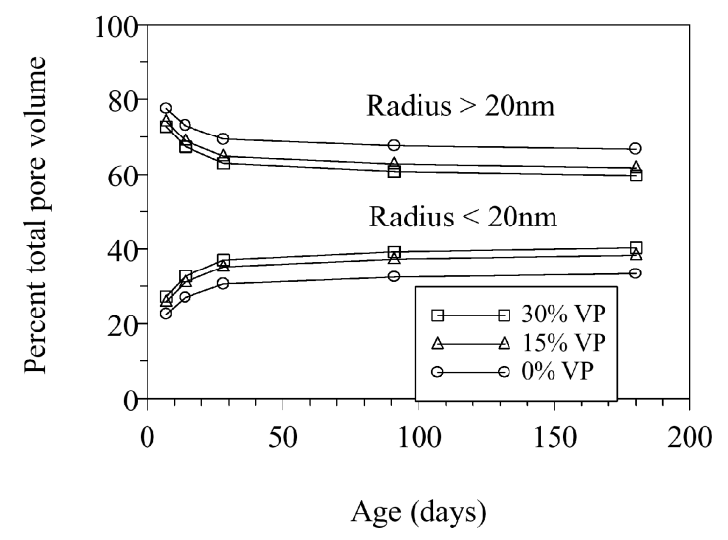

Fig. 6 Pore size distribution with curing age. 


\subsection{Compressive strength}

Figure 7 shows the variation of compressive strength of mortar specimens with curing age and \% of VP. The compressive strength is decreased with the increase of VP content in the mortars.

\subsection{Chloride ingress}

Figures 8 and 9 show the total chloride amount of the mortar specimens at 365 days of exposure. The chloride content at different depths decreased with the increase of VP content except on the surface. For both sets of specimens moist-cured for 7 and 28 days before exposure to the $5 \% \mathrm{NaCl}$ environment, the addition of VP to the cements results in a reduction in chloride ingress significantly beyond the depth of $25 \mathrm{~mm}$ compared with the mortars without $0 \%$ VP. The chloride ingress in 7day pre-cured specimens (Fig. 8) is higher compared to the 28-day pre-cured specimens (Fig. 9). 30\% cement replacement results in the lowest chloride ingress at deeper depths in both sets of specimens.

\subsection{Corrosion resistance}

Figure 10 shows the variation of OCP of the steel bars

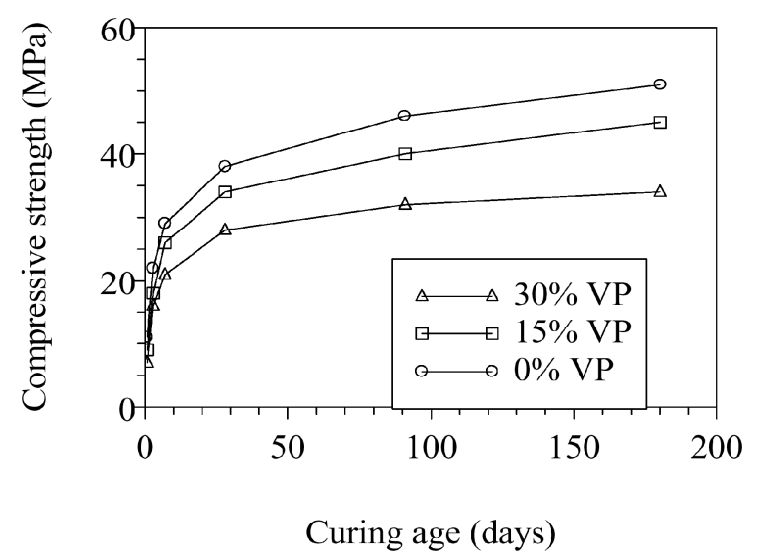

Fig. 7 Compressive strength as a function of curing age and VP content.

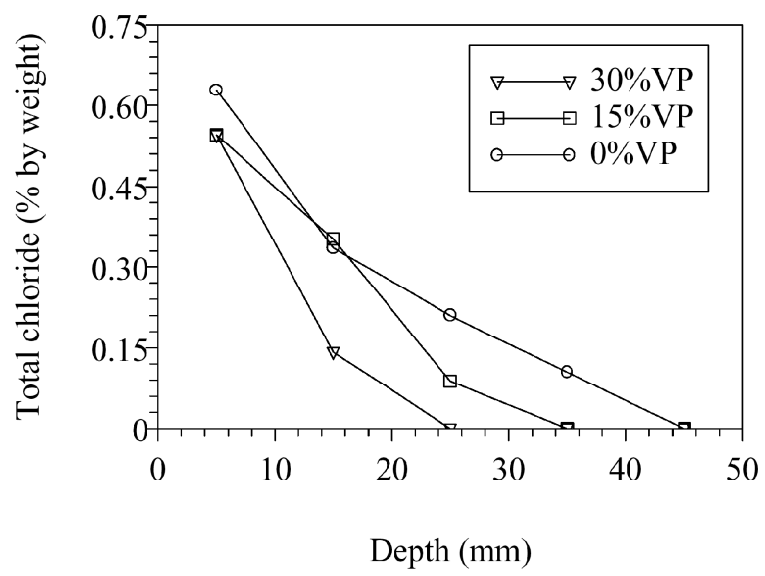

Fig. 8 Chloride concentration profile (7-day cured specimens). in the mortar blocks with age. The potential time curves were used to evaluate the time to initiation of rebar corrosion based on ASTM C 876 (1991) criterion of -270 $\mathrm{mV}$ SCE. Immediately after exposure, the potential readings were in the range 0 to $-180 \mathrm{mV}$, revealing a passive state. After a period that was de-pendent on the VP content, all the specimens showed potential decay towards more negative values, revealing the initiation of the corrosion process. The specimens with higher VP content showed less negative potentials than the specimens without VP. Specimens with $0 \%$ VP remained passive for about 2 weeks, whereas the specimens with $15 \%$ and $30 \%$ VP remained passive for about $6-7$ weeks. The time for activation increased with the increase of VP content in the mortar. Mortar blocks with $30 \%$ VP showed better corrosion resistance.

Table 4 shows the weight loss and corroded area of steel bars obtained from the physical measurements. It is seen that the weight losses and corroded area of steel bars embedded in the VP blended specimens are lower than those of control specimen ( $0 \% \mathrm{VP})$. Bars in $30 \%$ VP mortar specimens showed lowest corrosion with the lowest weight loss of only $0.10 \%$ and lowest corroded

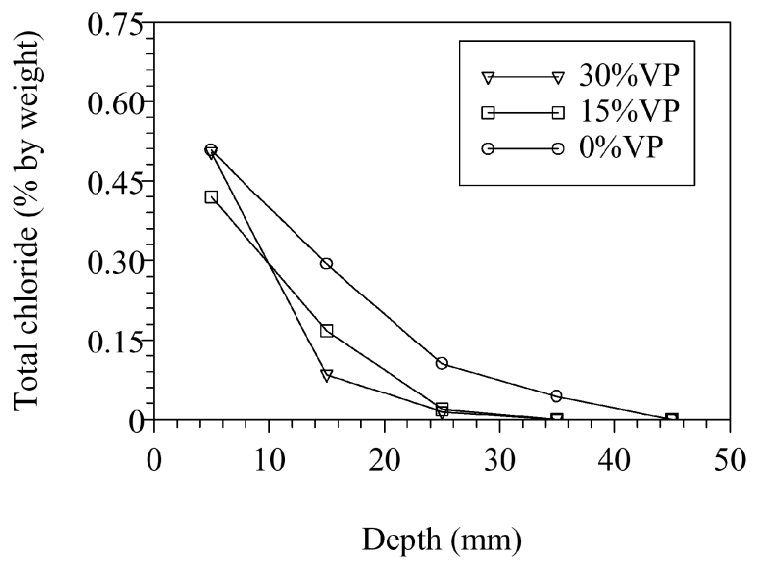

Fig. 9 Chloride concentration profile (28-day cured specimens).

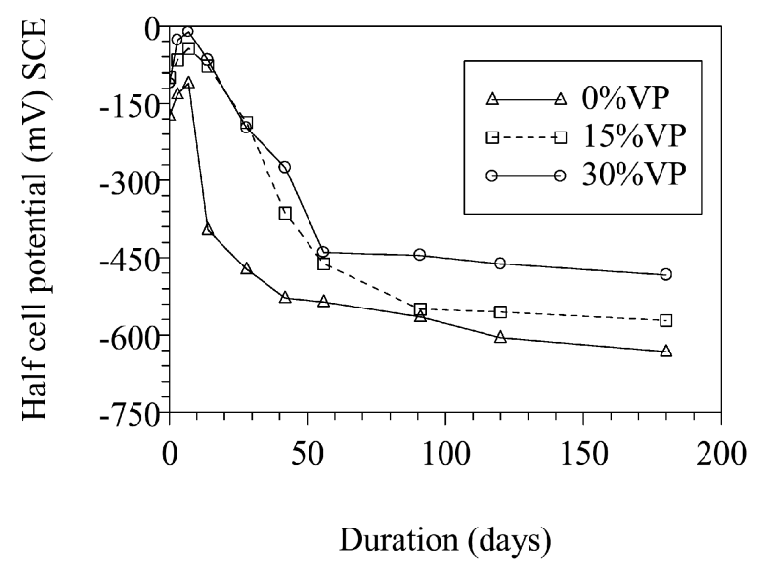

Fig. 10 Open circuit potential development in mortar specimens. 
Table 4 DSC and corrosion test results.

\begin{tabular}{|l|l|c|c|c|}
\hline \multirow{2}{*}{ Specimen } & \multicolumn{2}{|c|}{$\begin{array}{l}\text { 28-day precured } \\
365 \text { days curing age }\end{array}$} & \multicolumn{2}{l|}{ Endothermic peak area } \\
\cline { 2 - 5 } & $\begin{array}{l}\text { Weight } \\
\text { loss (\%) }\end{array}$ & $\begin{array}{c}\text { Corroded } \\
\text { area (\%) }\end{array}$ & $\begin{array}{c}\mathrm{Ca}(\mathrm{OH}) 2 \\
{[\mathrm{~J} / \mathrm{g}]}\end{array}$ & $\begin{array}{c}\text { Friedel's salts } \\
{[\mathrm{J} / \mathrm{g}]}\end{array}$ \\
\hline $0 \% \mathrm{VP}($ control) & 0.59 & 8.8 & 99 & 11 \\
$15 \% \mathrm{VP}$ & 0.38 & 5.8 & 52 & 18 \\
$30 \% \mathrm{VP}$ & 0.10 & 4.6 & 20 & 39 \\
\hline
\end{tabular}

area of $4.6 \%$.

\section{Correlation among various parameters}

Figure 11 shows a logarithmic scatter diagram of Di and electrical resistivity of the mortars. NPC $(0 \% \mathrm{VP})$ mortar shows relatively lower $\mathrm{D}_{\mathrm{i}}$ than others. $15 \% \mathrm{VP}$ mortar shows slightly lower $\mathrm{D}_{\mathrm{i}}$ than $30 \%$ VP. It also shows a good correlation between $\mathrm{D}_{\mathrm{i}}$ and electrical resistivity with $D_{i}$ being inversely proportional to electrical resistivity. This means that migration coefficient of chloride ion through cement mortars could be derived from the value of its electrical resistivity (Brown et al. 1991). Since electrical resistivity measurement is simple and nondestructive, such a relation would be very useful for researchers in this field.

Figure 12 shows the scatter diagrams of $D_{i}$ plotted on a log scale vs. TPV plotted on a normal scale. It is observed that there is a correlation between $\mathrm{D}_{\mathrm{i}}$ and TPV. The general trend shows an increase in $D_{i}$ with the increase of TPV in the mortars.

Figure 13 shows the scatter diagrams showing the relationship between the logarithm of electrical resistivity and TPV of the mortars plotted on normal scale. It is seen that there is no reasonable correlation and the logarithm of the electrical resistivity is inversely proportional to the total pore volume. However, for a constant $\mathrm{TPV}$, the electrical resistivity of the mortars is found to increase with the increase of VP content.

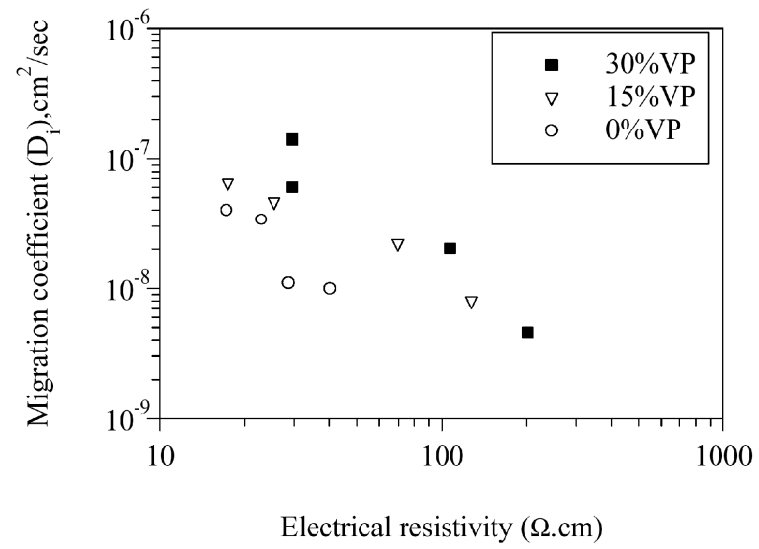

Fig. 11 Logarithmic correlation between $D_{i}$ and electrical resistivity.

\section{Discussion}

Table 4 shows the results of DSC for the mortars at a curing age of 365 day. The quantity of $\mathrm{Ca}(\mathrm{OH})_{2}$ formed in the hydration of the mortar decreases with the addition of VP. The endothermic peak for $\mathrm{Ca}(\mathrm{OH})_{2}$ was observed at around $460^{\circ} \mathrm{C}$. Lowering of $\mathrm{Ca}(\mathrm{OH})_{2}$ also indicates that the pozzolanic reactivity of VP consumes $\mathrm{Ca}(\mathrm{OH})_{2}$ resulting from the hydration of cement. The pozzolanic (Hossain 1999c) reaction of VP with $\mathrm{Ca}(\mathrm{OH})_{2}$, improves the corrosion resistance of VP blended mortar compared to NPC mortar (0\% VP). This is justified from the lower $\mathrm{D}_{\mathrm{i}}$ (Fig. 3), higher electrical resitivity (Fig. 4) and lower chloride ingress at deeper depth (Figs. 8 and 9) in VP blended mortar specimens compared to control ( $0 \%$ VP) mortar specimens as observed in the current study.

VP is added as fine granulates and upon hydration it has the capability of partially obstructing voids and pores. This leads to a decrease of pore size with refinement of pore structure and to a smaller effective diffusivity for chloride or other species as confirmed from the experimental results (Fig. 3 and Fig. 6). This can improve the long-term corrosion resistance of con-

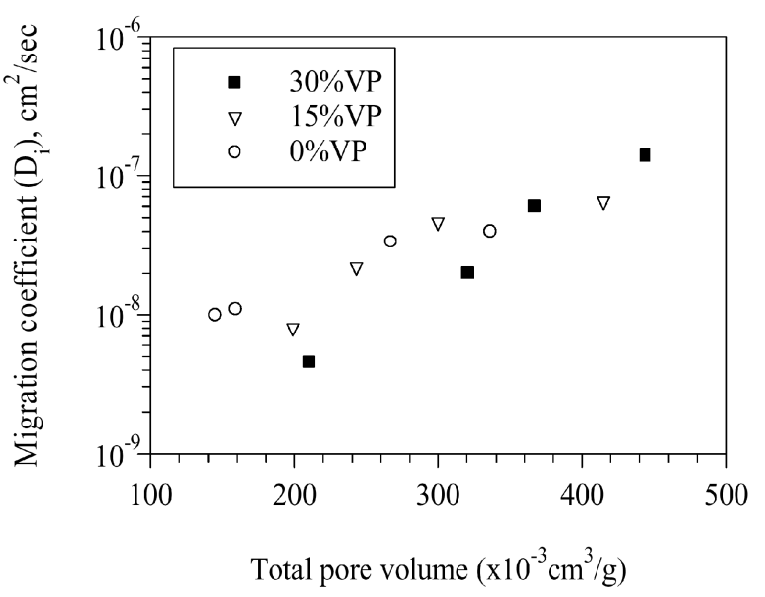

Fig. 12 Scatter diagrams of Di vs. TPV.

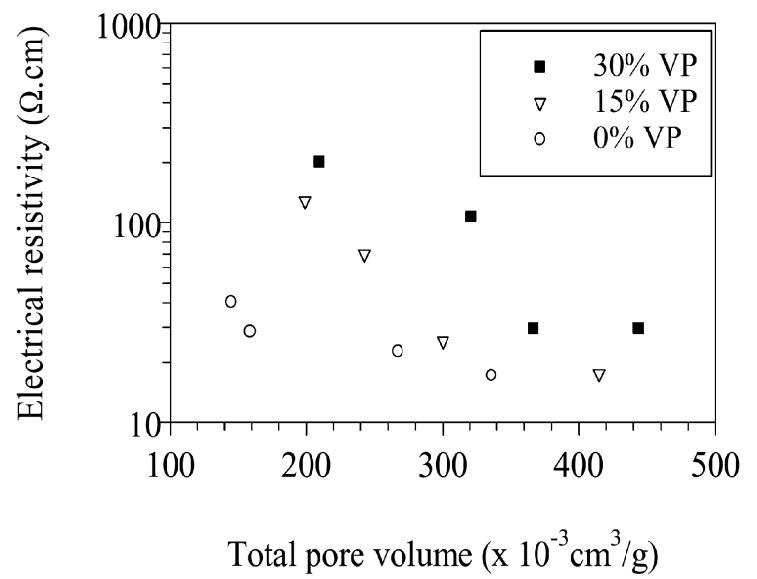

Fig. 13 Relationship between electrical resistivity and TPV. 
crete structures. The presence of VP also affects the composition and thickness of the passive films. The thickening of the passive films due to the presence of $\mathrm{VP}$ is confirmed from the lowering of corrosion area of steel bars (Table 4). The corrosion area of steel bar reflects the extent of destruction of passive film by chloride. However, the corrosion rate, in other words, oxidation reaction rate is also controlled by the amount of oxygen gas supply through cover concrete. Films formed in paste solutions have revealed a thickening and a higher degree of hydration under the influence of fly ash (Montemor et al. 1998).

The presence of VP strongly affects the chloride profile. Usually chlorides penetrate in concrete by diffusion along water paths or open pores. Part of these chlorides can react with the cement hydration products, mainly tricalciumaluminates $\left(\mathrm{C}_{3} \mathrm{~A}\right)$, forming stable chlorocomplexes. The excess of chloride is free and leads to the initiation of the corrosion process. The DSC analysis indicated the presence of Friedel's salts $\left(\mathrm{C}_{3} \mathrm{~A} \cdot \mathrm{CaCl}_{2} \cdot 10 \mathrm{H}_{2} \mathrm{O}\right)$ as an endothermic peak at around 3000C. Table 4 shows that the quantity of Friedel's salt increases with the addition of VP. This can be attributed to the fact that VP may have more amount of reactive alumina, which can adsorb more chloride ions to form Friedel's salts $\left(\mathrm{C}_{3} \mathrm{~A}\right.$ content of VP was not measured in the current study). Friedel's salt formation consequently lowers the levels of free chloride and hence reduces the chloride ion diffusivity of concrete. This process can reduce the localized corrosion of embedded steel in such mortar. Comparatively higher Friedel's salt formation in VP mortar compared to NPC mortar $(0 \% \mathrm{VP})$ is confirmed from DSC (Table 4) test results. The reduction in localized corrosion of embedded steel in VP blended mortar is confirmed from the lower weight loss and lower corroded area of steel bars (Table 4) in the current study. Similar phenomena were also observed in fly ash concrete (Koulombi et al. 1993).

Therefore, the overall effect of blending cement with VP will be: (a) to decrease the diffusivity of chloride ion through the resulting mortar, (b) to prolong the passivation period of embedded bars and (c) to improve the long-term corrosion resistance. Such beneficial effect of VP can be attributed to the refinement of pore structure, lowering the presence of free chloride due to Friedel's salt formation and pozzolanic action.

\section{Conclusions}

This paper describes the chloride diffusivity and corrosion resistance of VP blended mortar specimens with varying percentages of VP and curing age. The following conclusions can be drawn from various tests conducted in this study:

(1) The $D_{i}$ decreases with the increase of curing age. The long-term beneficial effect on chloride diffusivity is found to be better in mortars with higher \% of VP.

(2) $30 \%$ VP mortars have shown substantially higher electrical resistivity than $15 \%$ VP-mortars. The high electrical resistivity of VP blended mortars would enhance the overall resistivity of VP blended concrete and hence can induce a lower rate of bar corrosion after the breakdown of passivity.

(3) The incorporation of VP in mortar leads to refinement of the pore structure. The proportion of pores with radii smaller than $20 \mathrm{~nm}$ is increased as the replacement level of cement by VP increases. TPV also found to decrease with the increase of curing age.

(4) Correlation is found between $D_{i}$ and electrical resistivity of mortar. The logarithm of the electrical resistivity is inversely proportional to the total pore volume although there is a weak correlation.

(5) VP-blended specimens showed better resistance to chloride ingress with $30 \% \mathrm{VP}$ mortars exhibiting the lowest chloride ingress at deeper depths. The passivation period for the corrosion of steel bar is also increased in VP blended mortars. Bars in 30\% VP mortar specimens showed the lowest weight loss of only $0.12 \%$ and lowest corroded area of $5.1 \%$ in embedded steel.

(6) The presence of higher Friedel's salt and the lower quantity of $\mathrm{Ca}(\mathrm{OH})_{2}$ in VP mortar compared to NPC mortar $(0 \% \mathrm{VP})$ is an indication of the presence of lower levels of free chloride and an indication of the pozzolanic reaction of $\mathrm{VP}$ with $\mathrm{Ca}(\mathrm{OH})_{2}$ that produces a mortar with refined pore structure. These phenomena improve the chloride ion diffusivity and hence, higher corrosion resistance of VP mortar compared to NPC mortar (0\% VP).

\section{Acknowledgments}

The author is grateful to the Technical staffs of the materials laboratory of the Department of Civil Engineering of Papua New Guinea University of Technology for initial testing and preparation of specimens. Sincere gratitude to Tradescan Private Ltd, Bangladesh for providing generous voluntary financial assistance and the successful completion of the tests.

\section{References}

AASHTO T 277 (1983). "Standard method of test for rapid determination of the chloride permeability of concrete." American Association of State Highway and Transportation Officials. Washington D. C.

Al-Ani, M. and Hughes, B., (1989). "Pulverized-fuel ash \& it's uses in concrete." Magazine of Concrete Research, 41(147), 55-63.

ASTM C618-91, (1991). "Standard specification for fly ash and raw or calcined natural pozzolan for use as a mineral admixture in Portland cement concrete." Annual book of ASTM standards, Philadelphia, USA.

ASTM C 876 (1991). "Standard test method for Halfcell potentials of uncoated reinforcing steel in concrete." Annual book of ASTM standards, Philadelphia.

Berry, E.E. and Malhotra, V.M. (1980). "Fly ash for use in concrete - A critical review." Journal of ACI, 77 
(8), 59-73.

Bilodeau, A. and Malhotra, V. M. (1998). "High volume fly ash system: The concrete solution for sustainable development." In compilation of papers, three day CANMET/ACI symposium on sustainable development of the cement and concrete Industry, Ottawa 21-23 October, 193-214.

Broomfield, J. P., Langford, P. E., and Ewins, A. J. (1990). "In Corrosion rates of steel in concrete." (N. S. Berke, V. Chaker and D. Whiting (Eds)). ASTM STP 1065, Philadelphia, 157.

Brown, P. K., Shi, D., and Skalny, J. (1991). "Porosity / permeability relationships," in: J. Skalny, S. Mindees (Eds.). Materials Science of Concrete II, The American Ceramic Society. Westerville, Ohio, 83-109.

Gjorv, O. E. (1994). "Important test methods for evaluation of reinforced concrete durability, Concrete technology past, present, and future." ACI SP-144, 545-574.

Hossain, K. M.A. (1998a). "Volcanic ash and pumice based blended cement." Proc. of the 23rd conference on our world in concrete \& structures incorporating $3 r d$ international seminar on blended cements. Singapore 24 -26 August. CI-Premier Pte Ltd, 297-302.

Hossain, K. M.A. (1998b). "Volcanic ash as cement replacement material." Proc. of the IEPNG International Conference. Rabaul 25-27 September. Institute of professional engineers of Papua New Guinea, 3137.

Hossain, K. M. A. (1999a). "Effect of volcanic ash on cement based binder in concrete production." In modern concrete materials: binders, additions and admixtures, (R. Dhir and T. D. Dyer (Eds)), London, Thomas Telford Limited, 109-118.

Hossain, K. M. A. (1999b), "Properties of volcanic ash and pumice concrete." IABSE Report. 80, 145-150.

Hossain, K. M. A. (1999c). "Performance of volcanic ash concrete in marine environment." Proc. of the 24th OWICS Conference, "21st century concrete \& structures”. Singapore, 25-26 August, XVIII, CI Premier Pte Ltd, 209-214.

Hossain, K. M. A., and Uy B. (1999), "Characteristics of volcanic ash and pumice based concrete." Proc. of the international conference on mechanics of structures, materials and systems, University of Wollongong, Wollongong, Australia, 17-19 February, 239244.

JCI-SC 5. Japan Concrete Institute Standard. Tokyo, Japan.

Kawamura, M., and Torii, K. (1989). "Chloride permeability of concrete containing a fly ash and a blast furnace slag." Materials research society symposium proceedings, 137, 411- 416.

Koulombi, N., Batis, G., and Malami, C. H. (1993). "In Progress in the understanding and prevention of cor- rosion (J. M. Costa and A. D. Mercer (Eds))." vol. 1, The Institute of Materials, UK, 619.

Mangat, P. S., and Gurusamy, K. (1987). "Chloride diffusion in steel fibre reinforced concrete." Cement and Concrete Research. 17, 385-396.

Mehta, P. K. (1979). "Properties of Blended Cements Made from Rice Husk ash," Journal of ACI, 74, 440442.

Montemor, M. F., Simoes, A. M. P., and Salta, M. M. (2000). "Effect of fly ash on concrete reinforcement corrosion studied by EIS." Cement \& Concrete Composites. 22,175-185.

Montemor, M. F., Simoes, A. M. P., and Ferreira, M. G. S. (1998). "Analytical characterization of the passive film formed on steel in solutions simulating the concrete interstitial electrolyte." Corrosion. 54 (5), 347 353.

Montemor, M. F., Simoes, A. M. P., Salta, M. M., and Ferreira, M. G. S. (1993). "Carbonation of fly ash containing concrete- electrochemical studies." In: Proceedings of the 12th International Corrosion Congress. Houston, Paper no. 76, NACE.

Ping, G., Ping, X., Yan, F., and Beaudoin, J. J. (1995). "Microstructural characterization of cementitious materials: Conductivity and impedance method." Materials Science of Concrete IV, The American Ceramic Society, Westerville, Ohio, 201-262.

Swamy, R. N. (1983). "New Concrete Materials, Concrete Technology and Design." Vol.2, Surrey University Press, Great Britain.

Swamy, R. N. (1986). "Cement Replacement Materials, Concrete Technology and Design" Vol. 3, Surrey University Press, Great Britain..

Tang, L., and Nilsson, L. O. (1992). "Rapid determination of chloride diffusivity in concrete by applying electrical field." ACI Materials Journal, 89 (1), 49-53.

Thomas, M. D. A., and Matthews, J. D. (1996). "Chloride penetration and reinforced corrosion in marine exposed fly ash concretes." Proc. 3rd CANMET/ACI international conference on concrete in marine environment, (V.M. Malhotra (Ed.)) ACI SP-163, ACI, Detroit, 317-338.

Tritthart, J. (1999). "Ion transport in cement paste during electrochemical chloride removal." Advances in Cement Research. AC11 (04), 149-160.

Washburn, E. W. (1921). "Note on a method of determining the distribution of pore sizes in a porous materials." Proc. Int. Acad Sc. USA, 7,115-116.

Zhang, J. Z., and Bluenfeld N. R. (1994). "Development of the accelerated chloride migration test as a measure of chloride diffusivity in concrete." Proc. of International Conference on the corrosion and corrosion protection of steel in concrete, University of Sheffield. Sheffield, 1, 395-403. 